\title{
Analysis of Water Availability in Omu Watershed
}

\author{
M. Galib Ishak ${ }^{1, *}, I$ Wayan Sutapa ${ }^{1}$, Armin Basong $^{1}$ and Aditya Dedi $^{1}$ \\ ${ }^{1}$ Departement of Civil Engineering, Engineering Faculty, Tadulako University, 94221 Palu-Indonesia
}

\begin{abstract}
The availability of water in the Omu watershed becomes an important factor for residents in carrying out their activities, very it is important to know the available discharge and water requirements. This study aims to determine the amount of water availability in the Omu watershed based on the method FJ. MOCK, NRECA, and SMEC. This research uses average monthly rainfall data of Tuva station, average monthly climatology data of Bora station, data of catchment area, and land use. The result of the calculation of Omu watershed water availability by using the method of FJ. MOCK, NRECA, and SMEC; obtained the average discharge $2.21 \mathrm{~m}^{3} / \mathrm{sec}, 2.30 \mathrm{~m}^{3} / \mathrm{sec}, 2.85 \mathrm{~m}^{3} / \mathrm{sec}$, the maximum discharge happened in June $2.36 \mathrm{~m}^{3} / \mathrm{sec}$, in March $3.63 \mathrm{~m}^{3} / \mathrm{sec}$, in June $3.58 \mathrm{~m}^{3} / \mathrm{sec}$, and while the minimum discharge happened in July $1.72 \mathrm{~m}^{3} / \mathrm{sec}$, in January $0.84 \mathrm{~m}^{3} / \mathrm{sec}$, in February $2.12 \mathrm{~m}^{3} / \mathrm{sec}$. The result of instantaneous discharge measurement in the field is $2.18 \mathrm{~m}^{3} / \mathrm{sec}$. Based on the comparison of the results of the analysis of the water availability data on the Omu watershed, from the three methods closest to the instantaneous discharge value is the FJ. MOCK method.
\end{abstract}

\section{Introduction}

Water is one natural resource that has a very vital function for the life of living things that exist on earth. Humans and all other living things need water, [1]. Humans have an obligation to use them wisely and even required the existence of wise management and utilization, so that water can be preserved.

Water utilization will certainly be closely related to the availability and type of utilization such as water utilization for domestic (household), agriculture, fishery, animal husbandry, industry, and others. The existence of various interests in the utilization of water in various aspects can lead to conflicts both in the use of water and how to obtain it.

The level of water demand in various places varies, with the increasing number of people, the need for water increases.

With the increase of population, of course, will affect to the water needs of the population adapted to activities that have been done by the population, whether it is the need for water for domestic, agriculture, fishery, animal husbandry. Therefore, the availability of water in the Omu watershed becomes an important factor for residents in carrying out all activities to be undertaken, it is necessary to balance the availability of water and water needs.

\footnotetext{
* Corresponding author : galibishak@yahoo.co.id
} 
In this research to calculate the availability of water in the Omu watershed used the method. FJ. MOCK, NRECA, and SMEC, of the three methods, comparing the instantaneous discharge measurements that are by conducting directly in the river.

\section{Literature Review}

\subsection{Hydrological cycle}

In this research to calculate the availability of water in the Omu watershed used the method. FJ. MOCK, NRECA, and SMEC, of the three methods, comparing the instantaneous discharge measurements that are by conducting directly in the river.

According to Asdak [2], the water or hydrological cycle is a pattern of water circulation in the ecosystem that includes input in the form of rainfall and then distributed in several ways. Hydrological cycle from water travel from sea level to the atmosphere than to the soil surface and back to the sea continuously constantly. In addition, the water will also be suspended (temporarily) in rivers, lakes (reservoirs) and in soil that can be utilized by humans or other living things.

With the help of solar thermal energy and other climatic factors cause the evaporation process on the surface of vegetation and soil, in the sea or other bodies of water. Water vapour as a result of the evaporation process will be carried by the wind across the mountainous terrain and flat and if the atmosphere allows, some of the water vapour will condense and descend as rainwater.

\subsection{Model of hydrology the watershed}

The watershed as a hydrological system includes living organisms, physical and chemical environments that interact dynamically and therein a dynamic balance between energy and materials entering with energy and material out. In the natural state of solar energy, climates above the watershed and endogenic elements beneath the surface of the watershed are inputs, while the water coming out of the watershed and the water returning to the air through evapotranspiration is the watershed output, [3].

Basically the use of a model in hydrology includes the following: (1) Forecasting, including for warning and management systems, the notion of forecasting here shows both the magnitude and time of events analyzed by probabilistic way, (2) the sense contained in it is the magnitude of the event and the hypothetical future time, (3) As a means of detection in control problems, with a defined system and known outputs the inputs can be controlled and regulated, (4) As a means of identification, (5) Extrapolation of data or information, (6) Estimated environment due to changing or increasing human behaviour levels and (7) basic research in the hydrological process.

\subsection{Water availability}

Overall, the amount of water on planet Earth is relatively fixed from time to time, [4]. The availability of water that is part of a natural phenomenon, is often difficult to regulate and predict accurately. This is because the availability of water contains elements of spatial variability and variability of time (temporal variability) is very high. The concept of the hydrologic cycle is that the amount of water in a given area of the earth is affected by the input and the output. The water requirement in our life is very wide and always desirable in sufficient quantities at the right time. Therefore, the quantitative and qualitative analysis 
should be done as closely as possible in order to produce accurate information for planning and management of water resources.

\subsection{Definition of the river}

The river is a blend of river flow and the flow of water in it. The river channel is a long stretch above the earth's surface where the water flowing from the rainwater, [5].

\subsection{Watershed}

The basic concept of river flow or often abbreviated as the watershed is the basis of all hydrological planning. The large basin is basically composed of sub-watershed, and this Subwatershed is also composed of even smaller watersheds. According to Suripin [4], the watershed can be defined as an area bounded by natural boundaries, such as ridges or mountains, as well as artificial boundaries, such as roads or dykes, where rainfall that falls in the region contributes flow to the control point.

From the above definition, it can be argued that the watershed is an ecosystem, where the organisms and biophysical environment and chemical elements interact dynamically and in it, there is a balance of inflow and outflow of material and energy.

\subsection{Shape of the watershed}

According to Soewarno [6], the river pattern determines the shape of a watershed. The shape of the watershed has significance in relation to the flow of the river, which affects the speed of the central water. In general, the form of the watershed can be divided into four kinds, namely:

\subsubsection{The area flow of bird feathers}

The path of the area to the left of the right of the main river where the tributaries flow into the main river is called the flowing area of bird feathers. Such drainage areas have small flood because the time comes flooding from the tributaries to vary. Instead, the floods lasted a bit longer.

\subsection{Radial drainage area}

Fan-shaped drainage area, or circles and where the tributaries concentrate to a point radially are called radial drains. The drainage area with such features has a large flood near the confluence of the tributaries.

\subsubsection{Parallel drainage area}

This shape has a pattern in which the two paths of the streaming region are united in the streaming part united in the downstream. The flood occurred downstream of the confluence point of the rivers. 


\subsubsection{Drainage area of the complex}

Only a few stream regions have these shapes and are called complex drains.

\subsection{The discharge of the river}

The discharge of river water is the river water level measured by the river water level meter which is often used by the Automatic Water Level Record (AWLR) device, while another sense of flow or streamflow is the rate of water flow in units of water volume union time passing through a cross-section.

Rivers of one or more streams of water sources at altitudes, on a hill or many peaks or mountains, where rainwater that falls and collects in the basin then flows out through the lips of the basin, because the soil is saturated then becomes surface water that causes scouring thus forming a groove.

Furthermore, the water will flow to the lowest surface of the soil, perhaps first uniformly, but because there are parts of the surface of the soil that is not so hard, it is easily eroded, so that the groove that becomes more and more days longer, swift and increasingly frequent water flowing in the groove. The longer and deeper, the plot will turn, or branch, when the water flowing there is blocked by the rock as big as the groove, or the many rocks, as well as the subsurface stream, occurs from water flowing from above, then finds parts that can be penetrated beneath the surface of the soil and flow toward the low lowlands. over time the river will get wider, [7].

\subsection{Dependable flow}

Dependable flow is the discharge that is available throughout the year with a certain risk of failure, [8].

In the calculation of the dependable flow set of $80 \%$ water availability, it means there will be a discharge risk smaller than the water availability of $20 \%$. There are various ways that can be used in analyzing water availability. Each way has its own characteristics, the selection of appropriate methods is generally based on the following considerations:

- Available data

- $\quad$ Type of interest

- Experience

\subsubsection{Method of FJ. Mock}

In general, discharge analysis based on rainfall data which is often done in Indonesia is using an empirical method from Mock [9], that is water balance analysis to calculate monthly discharge price based on the transformation of monthly rainfall data, evapotranspiration, soil moisture and groundwater catchment [10-20].

The principle of the MOCK method states that rain falling in the catchment area, some will be lost by evapotranspiration, some will become direct runoffs and some will go into the soil or infiltrate. This infiltration will initially saturate the soil surface, then percolate to the groundwater and will come out as the base flow. There is a balance between falling rainwater with evapotranspiration, direct runoff and infiltration, where this infiltration is in the form of soil moisture and groundwater discharge. The flow in the river is the amount of flow directly at the ground surface and the base flow.

The monthly average rainfall in the river drainage area is calculated based on actual rainfall and evapotranspiration data from meteorological data using the Penman method and 
vegetation characteristics. The difference between rainfall and evapotranspiration results in a direct runoff, baseflow/groundwater flows, and storm runoff.

\subsubsection{Method of NRECA}

Method of NRECA is a rain-discharge simulation method introduced by Norman $\mathrm{H}$. Crawford in 1985. The NRECA model is a deterministic model of conception. The model of conception is a model with a theoretical basis, while the deterministic nature is the use of equations and semi-empirical formulas to interpret the phenomenon of its physical processes, [21].

\subsubsection{Method of SMEC}

Method of SMEC first created by SMEC consultants in 1982. This SMEC method is based on the type of catchment area. This method is the result of the analysis of the discharge data from 21 stations and the long-term average rainfall data so that the empirical equations are developed to provide an average monthly rainfall forecast in 2 and 5 years (possibly exceeded $50 \%$ and $80 \%$ ), [22].

\section{Research Methods}

\subsection{Types of research}

This research is descriptive research that aims to determine the availability of water in the Omu watershed.

\subsection{Location of research}

This research is administratively located in Omu Village Gumbasa District, Sigi Regency, Central Sulawesi with geographical location figure 1 at $1^{\circ} 16^{\prime} 44.36^{\prime \prime S}$ and $119^{\circ} 56^{\prime} 40.54^{\prime \prime}$.

The percentage of land use for the Omu watershed is as follows: $37 \%$ dry land primer forest, secondary dryland forest $28 \%$, rice field $7 \%, 12 \%$ mixed maze, dry land $7 \%$, road $4 \%$, settlement $5 \%$.

\subsection{Stages description of research}

The stages/descriptions of this study can be detailed as follows:

- Collection of data that has been done.

- Calculate the water supply discharge in Omu watershed based on 10 years of rainfall using FJ. MOCK, NRECA, and SMEC methods.

- Conducting a momentary discharge measurement in the field to determine the flow of the river.

- Conduct a comparative analysis of the calculation results using FJ. MOCK, NRECA, and SMEC methods then evaluated the results with the results of instantaneous discharge measurements in the field.

- A superior method of analysis is used to calculate the availability of water in the Omu watershed. 


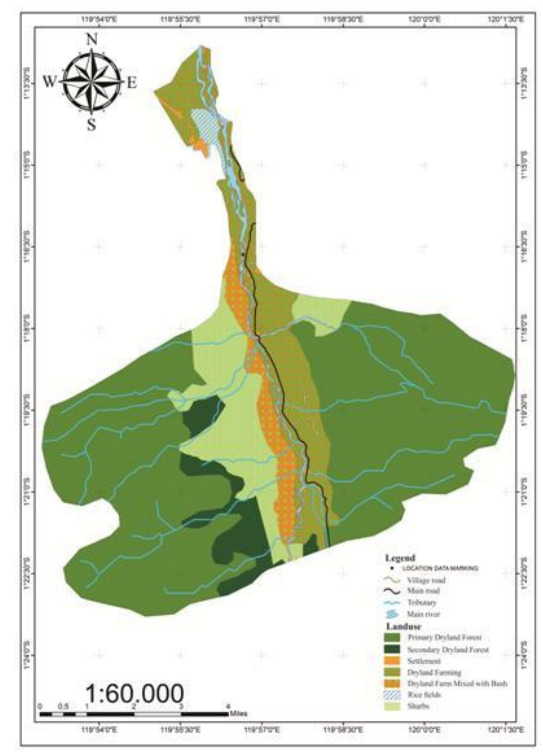

Fig. 1. Map of Omu Watershed

\section{Results and Discussion}

\subsection{Data compilation}

Compilation of data in "Water Supply Analysis in Omu River Basin" is based on secondary data to be used in the calculation and adjusted to the objectives to be achieved and the data is adjusted to its function. The data in question, including:

\subsubsection{Rainfall data}

Rainfall data is rain data that occurs in an area, rain data can be obtained from rain gauge or automatic rainfall, rain data taken is monthly rainfall data [6]. The rainfall data taken in this study is the Tuva rainfall station data because the rain gauge station is considered to be representative and closest to the study location with 10 years of rainfall data for the 2007 2016 period.

\subsubsection{Climatology data}

Climatology data is the observation data of weather elements such as temperature, humidity, solar irradiance and wind speed. This data is required as a water input in the river basin, and evaporation as one of the process of water loss [6]. Climatology data used for the location of the study that is using Bora Station because the rain gauge station is considered able to represent and closest to the study location with 10-year rainfall data period 2007-2016.

\subsection{Soil condition data}

Data soil condition is the data needed to determine the capacity of infiltration and evaporation that consists of the form of a grain of soil, pattern and precipitation. Based on observations 
and data obtained from the Meteorology, Climatology and Geophysics Agency of the Omu Watershed, including the type of gravel sand / porous soil.

\subsection{Calculation of evapotranspiration}

A potential evapotranspiration calculation is performed to find out how much evapotranspiration occurs in a given time unit $(\mathrm{mm} / \mathrm{month}$ or $\mathrm{mm} /$ day). For Evapotranspiration calculation in this study used $[10,20]$ that has been modified for calculation in the regions in Indonesia.

\subsection{Water availability calculation}

The calculation of water availability is used with three empirical methods namely FJ. MOCK, NRECA, and SMEC method. This method of steering in the analysis and the results will be compared through the result of the measured discharge approach in the field that has been carried out in this study. Here are the results of water availability calculation using FJ. MOCK, NRECA, and SMEC methods.

From the results of the calculation of the water availability of FJ. MOCK method produces an average discharge of $2.03 \mathrm{~m}^{3} / \mathrm{sec}$ with a watershed of $122.8 \mathrm{~km}^{2}$. From Figure 2 the comparison graph of the results of the calculation of the water availability method of FJ MOCK large enough monthly discharge occurred in June that has a discharge of $2.36 \mathrm{~m}^{3} / \mathrm{sec}$, while for the small monthly discharge that occurred in July that has a discharge $1.72 \mathrm{~m}^{3} / \mathrm{sec}$.

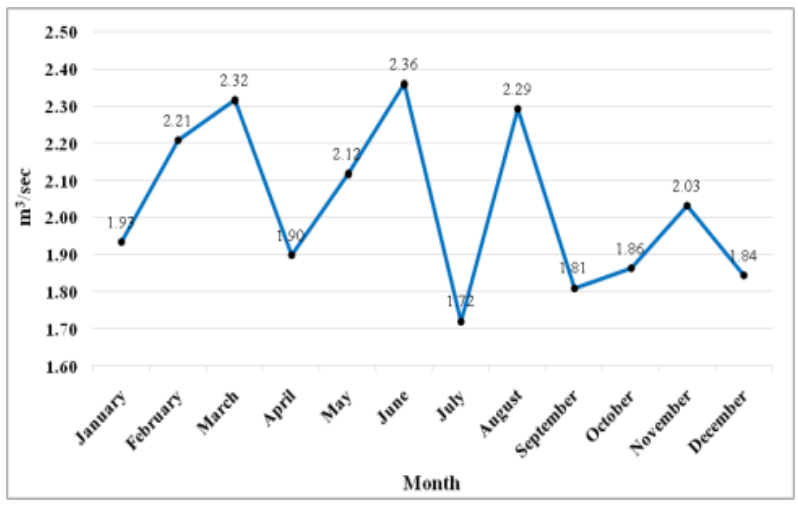

Fig. 2. Graph of discharge mainstay F.J. MOCK method.

Table 1. The result of water availability Method of F.J. MOCK

\begin{tabular}{|c|c|}
\hline \multirow{2}{*}{ Month } & Water availability \\
\cline { 2 - 2 } & Method of FJ. MOCK $\left(\mathbf{m}^{\mathbf{3}} / \mathbf{s e c}\right)$ \\
\hline January & 1.93 \\
\hline February & 2.21 \\
\hline March & 2.32 \\
\hline April & 1.90 \\
\hline May & 2.12 \\
\hline June & 2.36 \\
\hline July & 1.72 \\
\hline August & 2.29 \\
\hline
\end{tabular}




\begin{tabular}{|c|c|}
\hline September & 1.81 \\
\hline October & 1.86 \\
\hline November & 2.03 \\
\hline December & 1.84 \\
\hline Amount & 24.39 \\
\hline Average & 2.03 \\
\hline
\end{tabular}

From the results of the calculation of the water availability with NRECA method produces an average discharge of $2.30 \mathrm{~m}^{3} / \mathrm{sec}$ with a watershed of $122.8 \mathrm{~km}^{2}$. From Figure 3 comparison graph of the results of NRECA discharge calculation mainstay of large monthly discharge that occurred in March that has a discharge of $3.63 \mathrm{~m}^{3} / \mathrm{sec}$, while for the smallest monthly discharge occurred in January that has a discharge of $0.84 \mathrm{~m}^{3} / \mathrm{sec}$.

Table 2. The result of water availability Method of NRECA $\left(\mathrm{m}^{3} / \mathrm{sec}\right)$

\begin{tabular}{|c|c|}
\hline \multirow{2}{*}{ Month } & Water availability \\
\cline { 2 - 2 } & Method of NRECA $\left(\mathbf{m}^{\mathbf{3}} \mathbf{s e c}\right)$ \\
\hline January & 0.84 \\
\hline February & 2.97 \\
\hline March & 3.63 \\
\hline April & 2.46 \\
\hline May & 3.14 \\
\hline June & 3.43 \\
\hline July & 2.68 \\
\hline August & 1.90 \\
\hline September & 1.51 \\
\hline October & 1.53 \\
\hline November & 2.28 \\
\hline December & 1.27 \\
\hline Amount & 27.64 \\
\hline Average & 2.30 \\
\hline
\end{tabular}

From the results of the calculation of the water availability by SMEC method produces an average discharge of $2.85 \mathrm{~m}^{3} / \mathrm{sec}$ with a watershed of $122.8 \mathrm{~km}^{2}$. From picture 4 comparison graph of the result of discharge calculation of mainstay of SMEC method big, enough monthly discharge happened in June that has discharge equal to $3.58 \mathrm{~m}^{3} / \mathrm{sec}$, whereas for the smallest monthly discharge happened in the month of February that has discharge $2.12 \mathrm{~m}^{3} / \mathrm{sec}$. 


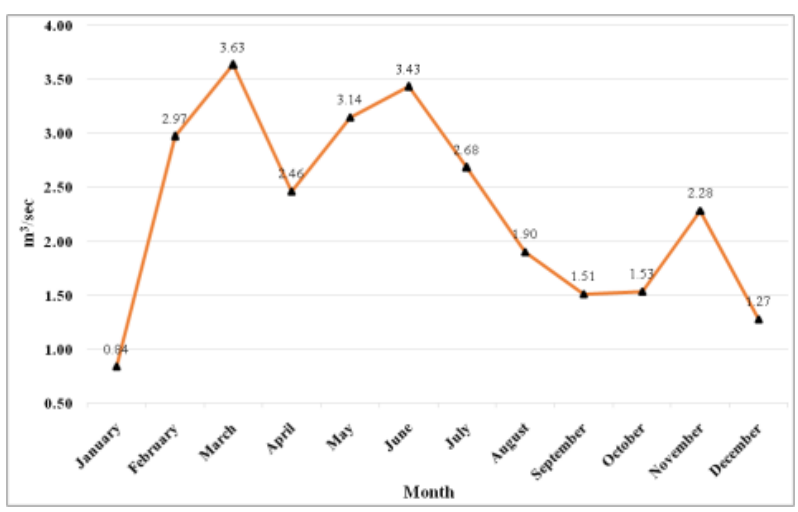

Fig. 3. Graph of discharge mainstay NRECA method

The results of instantaneous discharge calculations based on the measurement results in the field with the measurement time of 07 February 2018 obtained $Q=10.907 \mathrm{~m}^{3} / \mathrm{sec}$ so, the water availability in February by doing the measurement of instantaneous discharge is $\mathrm{Q}=$ $20 \% \times 10,907=2.181 \mathrm{~m}^{3} / \mathrm{sec}$.

Table 3. The result of water availability Method of SMEC $\left(\mathrm{m}^{3} / \mathrm{sec}\right)$

\begin{tabular}{|c|c|}
\hline \multirow{2}{*}{ Month } & Water availability \\
\cline { 2 - 2 } & Method of SMEC $\left(\mathbf{m}^{\mathbf{3}} / \mathbf{s e c}\right)$ \\
\hline January & 2.68 \\
\hline February & 2.12 \\
\hline March & 2.69 \\
\hline April & 3.09 \\
\hline May & 3.27 \\
\hline June & 3.58 \\
\hline July & 3.10 \\
\hline August & 2.96 \\
\hline September & 2.80 \\
\hline October & 2.47 \\
\hline November & 2.71 \\
\hline December & 2.71 \\
\hline Amount & 34.17 \\
\hline Average & 2.85 \\
\hline
\end{tabular}




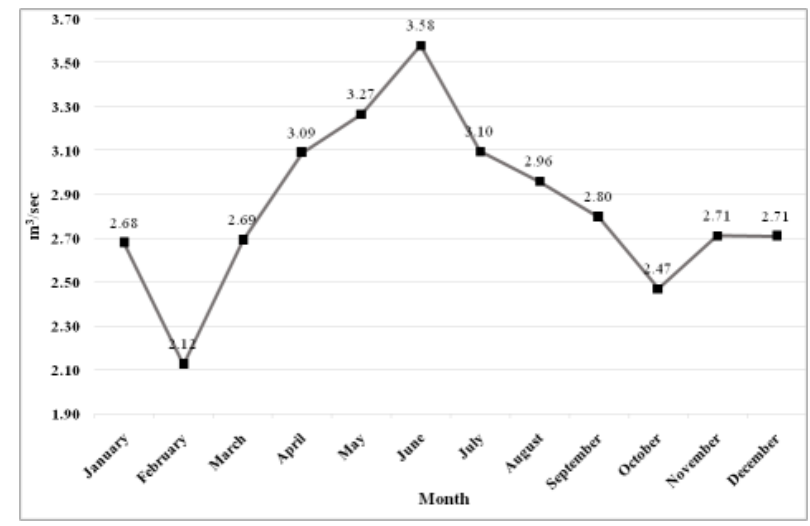

Fig. 4. Graph of water availability SMEC method

Table 4. Comparison of method calculation results MOCK, NRECA, SMEC, and Instant discharge

\begin{tabular}{|c|c|}
\hline Method & Discharge $\left(\mathbf{m}^{\mathbf{3}} / \mathbf{s e c}\right)$ \\
\hline FJ. Mock & 2.210 \\
\hline NRECA & 2.970 \\
\hline SMEC & 2.120 \\
\hline $\begin{array}{c}\text { Instantaneous } \\
\text { Measurement of } \\
\text { Discharge }\end{array}$ & 2.181 \\
\hline
\end{tabular}

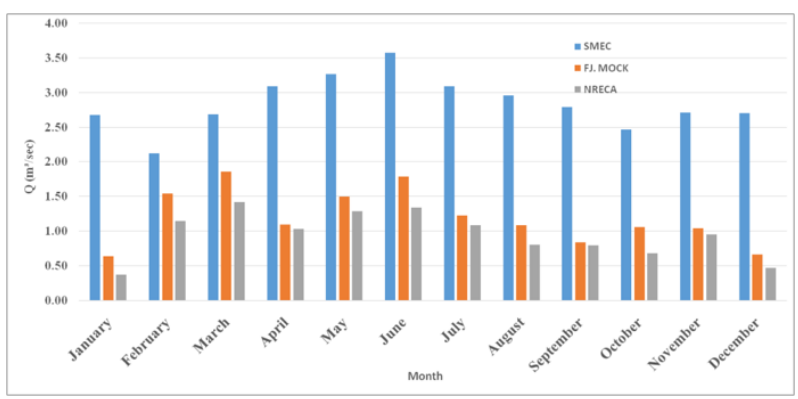

Fig. 5. Graph Comparison of Water availability Method of FJ. MOCK, NRECA, and SMEC 
A momentary discharge was taken in February so that the comparison of the results of the analysis of the reliable discharge calculation data using the FJ. MOCK, NRECA and SMEC methods were also taken in February. From the three methods can be seen that the method FJ. MOCK with the results of the calculation of the average water availability 2,210 $\mathrm{m}^{3} / \mathrm{sec}$ closer to the momentary discharge in the field that is $2.181 \mathrm{~m}^{3} / \mathrm{sec}$ difference between the results to the method FJ. MOCK and instantaneous discharge is $0.027 \mathrm{~m}^{3} / \mathrm{sec}$ according to figure 5. It can be said that for the calculation of water availability in Omu Watershed with $122.8 \mathrm{~km}^{2}$ of the river basin is more suitable to use FJ. MOCK method than NRECA and SMEC.

\section{Conclusion}

Based on the result of water availability analysis in Omu river basin with $122.8 \mathrm{~km}^{2}$ of the watershed area by using FJ. MOCK method obtained the average monthly plot of 2.10 $\mathrm{m}^{3} / \mathrm{sec}$, the NRECA method obtained the average monthly average of $2.30 \mathrm{~m}^{3} / \mathrm{sec}$, and the SMEC method obtained the average monthly average of $2.85 \mathrm{~m}^{3} / \mathrm{sec}$. Resort calculation instantaneous discharge measurements in the field obtained a discharge of $2.181 \mathrm{~m}^{3} / \mathrm{sec}$. By comparing the results of the calculation of instantaneous discharge measurements in the field it can be said that the FJ. MOCK method is more suitable to calculate the availability of water in the Omu River Basin. This is because the result of the calculation using FJ. MOCK method is obtained almost near the results of the calculation of instantaneous discharge measurements in the field compared to the method of NRECA and SMEC

\section{References}

1. R. J. Kodoatie, Ground Water System, Publisher ANDI Yogyakarta, (2012).

2. Asdak, Guidelines for Hydrology and Hydraulic Planning Building on the River, Bogor, (2002)

3. Galleguillos, Comparison of Two temperature differencing methods do estimate Daily evapotranspiration over a Mediterranean vineyard watershed from ASTER data, (2011)

4. Suripin, Preservation of Soil and Water Resources, Publisher Andi Jogjakarta, (2002)

5. S. Sosrodarsono, Improvement and Setting of the River, Publisher PT. Pradnya Paramita, Jakarta, (1984)

6. Soewarno, Hydrology Measurement and Processing of Hydrometric River Flow Data, Bandung, (1991)

7. I. B. D. P. Aryana, P. I P. G. Wiswa, A.P., D. M. Restu, D. P. Aditya, Pkm-P Morphological Characteristics of River Estuary Yeh Abe, in Kelating beach, Publisher University of Warmadewa Denpasar, (2015)

8. Montarcih, Hydrology of Basic Techniques. Malang, Publisher CV. Citra Malang. (2010)

9. F. J. Mock, Land Capacity Appraised Indonesia water Availability appraised, UNDP/FAO, Bogor, (1973

10. W. Junaida, Discharge Analysis Based on FJ Mock Model, (2013) 
11. IW. Sutapa, M. B. Rispiningtati, L. Montarcih, Effect of Climate Change on Water Availability of Bangga River, Central Sulawesi of Indonesia, J. Basic. Appl. Sci. Res., 3(2), 1051-1058 (2013)

12. IW. Sutapa, The Influence of Climate Change on Discharge Modeling, Post Graduate Dissertation of Brawijaya University, Malang, East Java, Indonesia, (2013)

13. IW. Sutapa, M. B. Rispiningtati, L. Montarcih, Model of MockWyn-UB for Assessing Water Availability due to the Effect of Climate Change, Proceedings of the International Seminar of Indonesian Hydraulic Engineering Experts Association, Yogyakarta, Indonesia, 8 September 2013

14. H. Nugroho, Hydrology Application, 1st ed. Malang, Indonesia, Jogja Mediutama, p.95-105 (2011)

15. A. G. Richard, Crop Evapotranspiration-Guidelines for Computing Crop Water Requirement-FAO Irrigation and Drainage Paper No. 56. Rome, Food Agriculture Organization of the United Nation, p. Chapter 2. (1998)

16. IW. Sutapa, Effect of Climate Change on Recharging Groundwater in Bangga Watershed, Central Sulawesi of Indonesia, Environ. Eng.Res.J. 22(1), (2017)

17. IW. Sutapa, Application Model Mann-Kendall and Sen'S (Makesens) for Detecting Climate Change. Infrastructure J. Civil Eng. Univ. Tadulako. 4, 31-40 (2014)

18. IW. Sutapa, Long-Term Trend Climatology in Sigi, Central Sulawesi province. National Seminar on Civil Engineering Narotama of University, February 28, 2015, Surabaya. p.267-277 (2015)

19. IW. Sutapa, Study Water Availability of Malino River to Meet the Need of Water Requirement in District Ongka Malino, Central Sulawesi of Indonesia, 7 (3), 10691075 (2015)

20. A. S. Ansari, IW. Sutapa, M. G. Ishak, Model Hydrology MockWyn-UB to Analyse Water Availability in Gumbasa Watershed Central Sulawesi Province, Int. Journal of Engineering Research and Application, 7(1), 94-101 (2017)

21. H, N. Crawford \& M. S. Thurin, Hydrologic Estimate for Small Hydroelectric Projects, National Rural Electric Cooperative Association (Nreca) 1800 Massachusetts Avenue NW. Washington, DC 20036, (1981)

22. IW. Sutapa, M. G. Ishak, Application of non-parametric test to detect trend rainfall in Palu Watershed, Central Sulawesi, Indonesia, Int. J. Hydrology Science and Technology, 6, 3 (2016) 